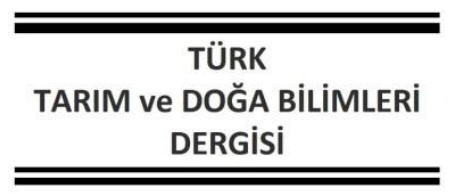

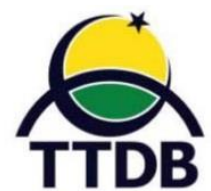

www.dergipark.gov.tr/turkjans

Araştırma Makalesi

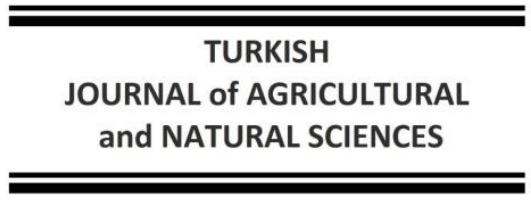

\title{
Farklı Mekânsal Enterpolasyon Yöntemleriyle Alansal Yağış Hesaplanması: Kuzey Ege Havza Örneği
}

\author{
Abdul Kadir AKACAK ${ }^{1}$, İsmail TAŞ ${ }^{2 *}$ \\ ${ }^{1}$ Çanakkale Onsekiz Mart Üniversitesi Lisansüstü Eğitim Enstitüsü Tarımsal Yapılar ve Sulama Anabilim Dalı, \\ Çanakkale \\ ${ }^{2}$ Çanakkale Onsekiz Mart Üniversitesi Ziraat Fakültesi Tarımsal Yapılar ve Sulama Bölümü, Çanakkale \\ *Sorumlu Yazar: tas_ismail@yahoo.com
}

Geliş Tarihi: 09.02.2021 Düzeltme Geliş Tarihi: 15.04.2021 Kabul Tarihi: 18.04.2021

Öz

Bir drenaj havzasında yağış yüksekliğinin belirlenmesi, havza su potansiyelinin hesaplanmasında hayati öneme sahiptir. Bilindiği gibi yağış, zamansal ve mekansal olarak değişkenlik gösteren meteorolojik bir olaydır. Havzanın topoğrafyasına bağı̆ı olarak büyük oranlarda farklııılar gösterir. Çalışmada Coğrafi Bilgi Sistemleri'nden (CBS) yararlanılarak Kuzey Ege Havzasının (KEH), ortalama yağış yüksekliği hesaplanmıştır. Havza içi 5 ve havza dışı 8 adet meteoroloji istasyonunun uzun yıllar ortalama yağış verilerinden yararlanılmıştır. Çalışmada, hem mekansal analiz yöntemleri, hem de jeoistatistik analiz yöntemleri kullanılarak alansal yağış yüksekliği hesaplanmıştır. Çalışmanın sonunda, jeoistatistiksel yöntemlerden biri olan Kernel Smoothing yönteminin Kuzey Ege Drenaj Havzasının alansal yağış yüksekliğinin hesaplanmasında kullanılabilecek en uygun yöntem olduğu belirlenmiştir. Havzanın ortalama yağış yüksekliği $748.61 \mathrm{~mm}$ olarak hesaplanmıştır.

Anahtar Kelimeler: Jeoistatistik, Mekansal Analiz, Yağış Yüksekliği

\section{Calculation of Spatial Precipitation with Different Spatial Interpolation Methods: A Case Study of The North Aegean Basin}

\begin{abstract}
Height of precipitation plays a vital role in water potential of drainage basins. Precipitation is a meteorological phenomenon that exhibit significant spatial and temporal variations. It also varies greatly depending on the topography of the basin. In the study, the average precipitation height of the North Aegean Basin (KEH) was calculated by using Geographical Information Systems (GIS). Long-term average rainfall data of 5 in-basin and 8 non-basin meteorology stations were used. In the study, spatial precipitation height was calculated using both the spatial analysis methods and geostatistical analysis methods. At the end of the study, it was determined that the Kernel Smoothing method, which is one of the geostatistical methods, was the most suitable method to be used in calculating the spatial precipitation height of the North Aegean Drainage Basin. The average precipitation height of the basin was calculated as $748.61 \mathrm{~mm}$.
\end{abstract}

Keywords: Geostatistics, Spatial Analysis, Precipitation Height

\section{Giriş}

Hidrolojide, su kalitesi ve su yönetimi çalışmalarında, yağış yüksekliği verisi en önemli parametredir. Yağış yükseklikleri, yağış gözlem istasyonlarındaki standart yağış ölçeklerinde noktasal olarak mm birimiyle ölçülür. Yeryüzündeki her noktaya bir gözlem istasyonu kurma olanağı bulunmadığı için her noktada gözlem yapmak da mümkün değildir. Ayrıca, tek bir ölçer kullanılarak belirlenen yağış yüksekliği, yüzey akışında belirsizliklere neden olmaktadır (Faures ve ark., 1995; Chaubeya ve ark., 1999; Çıtakoğlu ve ark., 2017). Ayrıca, havza bazında yapılan büyük ölçekli su kaynaklarının sürdürülebilir yönetim 
çalışmalarında yağış verilerinin zamansal ve özellikle mekânsal değişimi önemli bir parametredir. Bu nedenle, mühendislik çalışmalarında sıkça ihtiyaç duyulan ve belirlenmiş bir alan üzerindeki ortalama yağış derinliğini ifade eden alansal yağışın ölçülmesi de olası değildir (Çetin, 1996). Hidrolojik değişkenlerin haritalamasında kullanılan yöntemlerden bir tanesi de Üçgensel Hidrolojik Enterpolasyon (ÜHE) yöntemidir. Bu yöntem, yerleşik bölgesel değişkenler üzerinde uygulanmakta olup her bir üçgenin düğüm noktaları arasında basit kübik enterpolasyon yapılmaktadır. Önsoy ve Bayram (2011a), bu yöntemi kullanarak Türkiye'de üçgenler ağı oluşturmuş ve yağış değerlerinden oluşturulan korelasyon matrisinde öz vektör değerlerinde uyguladıklarında diğer yöntemlerle benzer sonuçlar elde edildiğini belirtmişlerdir.

Türkiye'nin tamamı UHE, Thiesen ve enterpolasyonlu elle çizim yönteminin uygulandığı bir çalışmada, tahmin edilen yağış değerlerinin birbiri ile çok yakın olduğu ve UHE yönteminde, her bir üçgen ünite içerisinde varyansın sabit olması kabulü, üçgen üniteler büyüdükçe, zayıflayacağı belirtilmektedir (Önsoy ve Bayram, 2011b).

KEH yağış ölçüm istasyonları, Diaz ve Karl'ın (1994) yağış istasyon sıklığı dikkate alındığında orta yoğun (istasyon başına $1990.44 \mathrm{~km}^{2}$ ) sınıfa girse de topoğrafya dikkate alındığında düşük yoğunlukta istasyona sahip kabul edilebilir. Araştırmacılara göre 25 ile $250 \mathrm{~km}^{2 \prime}$ lik alana bir istasyon düşen bölgeler yoğun, 250 ile $2500 \mathrm{~km}^{2 \prime}$ lik alana bir istasyon düşenler orta ve $2500 \mathrm{~km}^{2}$ 'den büyük bir alana bir istasyon düşenler ise düşük istasyon yoğunluğuna sahiptir. Türkiye bu durumda orta derecede istasyon yoğunluğuna sahiptir. Bunun yanında Türkiye'de istasyonların dağılışında bölgeler arasında büyük farklılıklar bulunmaktadır. Türkiye'de istasyon dağılımları genellikle yerleşmelerin yakınına kurulmuştur. Bu nedenle batı bölgelerinde istasyon sıklığı daha yüksek, doğuda ise daha düşüktür. Ayrıca Türkiye'de topografya kısa mesafede hızla değişmektedir. Bu durum da meteorolojik parametrelerin kısa mesafede büyük farklılıklar göstermesine neden olmaktadır. Türkiye'de yüksek dağlık alanlarda çok az sayıda meteorolojik istasyon bulunmaktadır. Oysa yüksek dağlık alanlarda yağan karın su potansiyeli çok önemlidir.

Jeoistatistik, belli bir gözlem alanı içerisinde belirli bir yapıya sahip gözlemi bulunmayan yöresel değişkenler ile gözlemi bulunan değişkenler arasında konumlarına göre enterpolasyon yaparak değişkenlerin tahmin edilmesini sağlar. Jeoistatistiksel analizin birinci ve en önemli aşaması gözlem alanı içerisindeki uzaysal bağımlılık yapısını ortaya koyan yarı variogram analizleridir (Keskiner, 2008).

Bilindiği gibi kompleks topografyaya sahip bölgelerde özellikle iklim parametreleri ve buna bağlı diğer değişkenler çok kısa mesafelerde dikkate değer şekilde değişmektedir. Bu nedenle çok fazla değişkenlik sergileyen iklim parametrelerinin doğru şekilde ölçülebilmesi için çok sık dağıtılmış ölçüm istasyon ağı ile gözlemlenmesi gerekmektedir. Başta ekonomik nedenler olmak üzere diğer bazı etmenler nedeniyle bu işlem pek mümkün olmamaktadır. Bu nedenle alternatif olarak dikkate alınan yöntemlerden bir tanesi de noktasal olarak ölçülen gözlem değerlerinin, alansal dağılım özelliği gösteren iklim veri katmanlarının modellenmesidir (Daly ve ark., 1994; Güler ve Kara, 2007). Dağlık alanlarda yağışların mekansal dağılımı, yüzey orografisi tarafından güçlü bir şekilde kontrol edilmektedir. Genel olarak, yağış sürecini etkileyen karmaşık faktörlerin kombinasyonu nedeniyle orografik yağış miktarının ölçülmesi ve homojen alanların belirlenmesi oldukça zordur. Güney İtalya'daki ortalama yıllık yağışların jeoistatistiksel yöntemle haritalanmasına yönelik yapılan bir çalışmada, $250 \times 250 \mathrm{~m}$ grit hücrelerinden meydana gelen sayısal yükseklik modeli oluşturulmuş ve Poligon kriging kullanılarak yağış haritaları üretilmiştir. Hazırlanan bu haritalarda dağlık alanlar, düşük rakımlı alanlara nazaran daha fazla yağış aldığı belirlenmiştir (Buttafuoco ve Lucà, 2020).

Türkiye'deki yağışların analizine yönelik çok sayıda araştırma yapılmıştır. Toros ve ark. (1994), 68 istasyonun ölçülen yağış değerlerine istatistik analiz yapmış, Anteplioğlu ve Şen (1994), İstanbul Kandilli Rasathanesi ölçülen yağış verilerine Mann-Kendall seri rank istatistiği ile trend analizini incelemiş, Çıtakoğlu ve ark., (2017), mevsimsel yağış değerlerine yapmış oldukları tanımlayıcı istatistikleri sonucunda sonbahar ve yaz aylarında daha büyük olmakla birlikte tüm mevsimlerdeki yağış değerlerinin sağa çarpık olduğunu, ve Cs katsayısı göz önüne alındığında, mevsimsel yağışların normal dağılıma uymadığını saptamışlardır. Ayrıca, yağış yüksekliklerinde meydana gelen değişkenliklerde önemli olup Türkiye özelinde yapılan bir çalışmada Akdeniz ve Güneydoğu Anadolu Bölgelerindeki yağışlarda değişkenliği \%25'den fazla olduğu saptanmıştır. En az değişkenlik Doğu Karadeniz Bölümü'nde belirlenmiştir. Uzun yıllara ait yağışlardaki oynaklıklar nedeniyle sıklıkla kuraklıklar yaşanmaktadır (Ölgen, 2010).

Genel olarak ülkemizin engebeli bir yapıya sahip olması nedeniyle her noktada yağış ölçümü hem çok zor hem de maliyetli bir işlemdir. Bu nedenle ölçüm yapılmayan yerlerin durumunu ortaya koymak için enterpolasyon tekniklerinden faydalanmak şarttır. Bu çalışmada, CBS ortamında 
alansal yağış hesaplanmasında kullanılabilecek en uygun mekânsal analiz yöntemi (hem jeoistaitisitik hem de spatial analiz) belirlenmiş ve KEH'nin ortalama yağış yüksekliği hesaplanmıştır.

\section{Materyal ve Yöntem Materyal}

Kuzey Ege Havzası, Anadolu Yarımadası'nın batı kesiminde $38-40^{\circ}$ Kuzey ile $26-28^{\circ}$ Doğu meridyenleri arasında yer almaktadır. Kuzeyinde Marmara Havzası, güneyinde Gediz Havzası, batısında Ege Denizi ve doğusunda Susurluk Havzası bulunmaktadır (Anonim, 2019). Havza sınırı Şekil 1'den de görüleceği gibi, kuzeyde Çanakkale Boğazı'ndan başlar ve Kayalıdağ (879 m), Kazdağ (1.766 m) ve Kocakatran Dağları; doğuda Havran, Bergama, Soma ve Kırkağaç sınırları boyunca uzanır; Güneydeki Kılıçdağ, Dumanlıdağ'ın su kesimi hattından (1.098 $\mathrm{m})$ geçerek, Foça ilçesi yakınlarında Ege Denizi'ne bağlanmaktadır (Anonim, 2017). Kuzey Ege Havzası 995220 ha'lık toplam alana (yapay alanlar, tarımsal alanlar, orman ve yarı doğal alanlar, ıslak alanlar ve su yüzeyleri dâhil) sahip olup Türkiye'nin toplam yüzölçümünün yaklaşık \%1.3'üne karşılık gelmektedir.

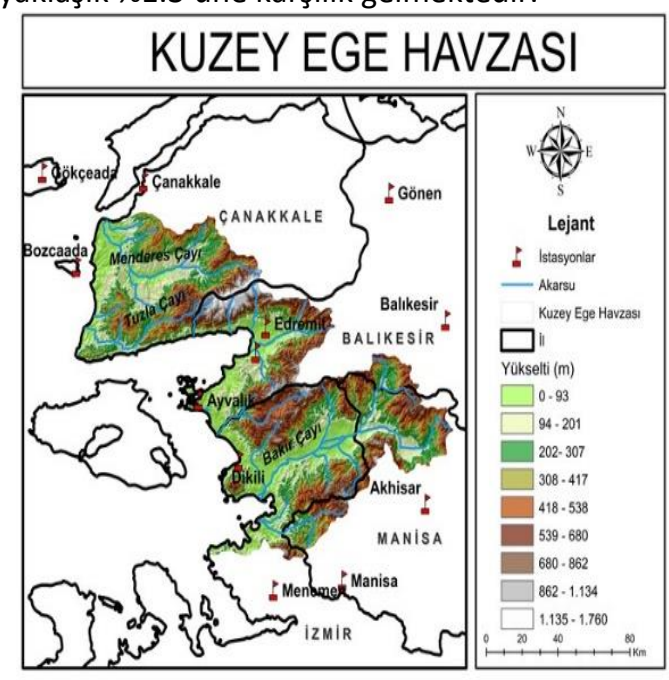

Şekil 1. Kuzey Ege Havzası

Havza sınırı içerisinde en çok paya sahip olan \%31.99 ile Çanakkale ilinin ardından \%25.23 ile İzmir ili, \%15.56 ile Balıkesir ili ve \%11.36 ile Manisa ili yer almaktadır (Büke, 2019).

Havzanın önemli akarsuları Çizelge 1'de gösterilmiştir. Söz konusu Çizelgeden de görülebileceği gibi Yağcılar Çayı'nı kapsayan Bakırçay Nehri, Karamenderes Çayı, Güzelhisar Çayı, Havran Çayı ve Madra Çayı'ndan oluşmaktadır. Bu akarsular dışında mevsimlik yağışlar ile oluşan pek çok akarsu da bulunmaktadır (Lekesiz, 2018).

Çizelge 1. Kuzey Ege Havzasında Yer Alan Akarsular ve Uzunlukları

\begin{tabular}{llr}
\hline No & Akarsu & Uzunluk $(\mathrm{m})$ \\
\hline 1 & Bakırçay & 120309 \\
2 & Karamenderes Çayı & 69851 \\
3 & Madra Çayı & 48195 \\
4 & Tuzla Çayı & 42661 \\
5 & Koca Çayı & 38223 \\
6 & Güzelhisar Çayı & 12872 \\
7 & Havran Çayı & 9303 \\
8 & Edremit Çayı & 9033 \\
9 & Akçin Çayı & 8468 \\
\hline
\end{tabular}

Coğrafi konumu nedeniyle havza yazın kurak ve sıcak, kışın ise ılık ve yağışlıdır. Yaz aylarında ortalama sıcaklık 24.9 ile $26.8^{\circ} \mathrm{C}$, kışın ortalama sıcaklık 6.2 ile $7.8^{\circ} \mathrm{C}$ arasında değişmektedir. Aralık en yüksek ortalama yağışa, Ağustos ayı en düşük yağışa sahiptir. Çanakkale'de Ocak ve Şubat aylarında ölçülen karla kaplı gün sayısı 1.3 'tür.

Ege Denizi'nin etkisi hemen hemen tüm havzada kendini göstermektedir. Doğu-batı yönünde ve kıyıya dik uzanan yüksek bir dizinin oluşumu, denizel etkinin havzaya nüfuz etmesini sağlar. Ancak Soma, Kırkağaç ve Savaştepe bölgeleri iç bölgelere göre daha iç kesimdedir ve bu durum havzanın diğer bölgelerine göre bu bölgelerde biraz daha karasal bir iklime sahip olmasına neden olmaktadır (Anonim, 2012)

$\mathrm{KEH}$ yağış ölçüm istasyonlarının yoğunluğu Diaz ve Karl'ın (1994) yağış istasyon sıklığı dikkate alındığında orta yoğun (istasyon başına 1990.44 $\mathrm{km}^{2}$ ) sınıfa girse de topoğrafya dikkate alındığında düşük yoğunlukta istasyona sahip kabul edilebilir. Bu veriler ile $\mathrm{KEH}^{\prime}$ nin yükselti haritası $\mathrm{CBS}$ ortamında birleştirilmiştir. KEH sınırları içerisinde yağış analizleri yapılabilmesi için noktasal yağış değerleri alansal yağışa dönüştürülmüştür. Bu işlem için CBS'nin uygun modüllerinden yararlanılmıştır.

$\mathrm{Bu}$ çalışmada, Meteoroloji Genel Müdürlüğü’ne ait Kuzey Ege Havza sınırları içinde ve çevresinde bulunan meteoroloji istasyonlarının uzun yıllar ortalama maksimum yağış verileri kullanılmıştır. Havza sınırları içinde bulunan 5 istasyon ve havza dışından 8 istasyon verilerinden yararlanılmıştır. Çalışmada verilerinden yararlanılan istasyonlar ve onlara ait bazı bilgiler Çizelge 2'de verilmiştir. Çalışmada gözlem istasyonlarının 19802010 yıllarını kapsayan 30 yıllık uzun yıllar ortalama verileri kullanılmıştır. 
Çizelge 3. Çalışmada Kullanılan Meteoroloji İstasyonları

\begin{tabular}{lllcccc}
\hline \multirow{2}{*}{ No } & İçi/Dış & i̇stasyon Adı & Enlem & Boylam & $\begin{array}{c}\text { Rakım } \\
(\mathrm{m})\end{array}$ & $\begin{array}{c}\text { Ortalama Yağış } \\
\text { Yüksekliği }(\mathrm{mm})\end{array}$ \\
\hline 1 & İçi & Ayvalık & 393056 & 266824 & 41 & 632 \\
2 & İçi & Bergama & 391052 & 271685 & 44 & 627 \\
3 & İçi & Burhaniye & 394904 & 269681 & 20 & 616 \\
4 & İçi & Dikili & 390707 & 268828 & 8 & 568 \\
5 & İçi & Edremit & 395848 & 270183 & 18 & 681 \\
6 & Dış & Akhisar & 389032 & 278174 & 86 & 549 \\
7 & Dış & Balıkesir & 396150 & 279186 & 107 & 544 \\
8 & Dış & Bozcaada & 398230 & 260701 & 28 & 469 \\
9 & Dış & Çanakkale & 401527 & 264067 & 10 & 592 \\
10 & Dış & Gökçeada & 401871 & 259009 & 72 & 723 \\
11 & Dış & Gönen & 401077 & 276364 & 40 & 663 \\
12 & Dış & Manisa & 386067 & 274012 & 152 & 686 \\
13 & Dış & Menemen & 385688 & 270567 & 10 & 468 \\
\hline
\end{tabular}

\section{Yöntem}

Bir arazide değişik bölgelerden alınan örnekleme değerlerini kullanarak herhangi bir noktanın değerini tahmin etme işlemine "enterpolasyon" adı verilmektedir. Genellikle enterpolasyon, verilerin toplandığı alanın dışından ziyade içerisindeki bir alana ait verilerin tahmin edilmesinde kullanılır. İki farklı enterpolasyon tekniği vardır. Bunlar; deterministik ve stokastik (jeoistatistik) yöntemlerdir (Isaaks ve Srivastava 1989; Anonymous, 2004; Tural, 2011). Her iki teknikte başka bir konuma ait değerlerin hesaplanmasında çevredeki örnekleme noktalarına ait ölçülen değerleri kullanmaktadır. Deterministik teknikler enterpolasyon işleminde matematiksel fonksiyonları kullanırken, Stokastik (jeoistatistik) yöntemler tahmin işlemindeki belirsizlik ve hataları da ortaya koyabilecek şekilde hem matematiksel hem de istatistiksel fonksiyonları dikkate alarak işlem yapmaktadır (Anonymous, 2004; Tural, 2011).

Deterministik enterpolasyon teknikleri, benzerlik kapsamına veya düzgünleştirme derecesine bağıı olarak ölçülen noktalardan yüzeyler oluşturur. Jeoistatistik enterpolasyon teknikleri ölçülen noktaların istatistiksel özelliklerini kullanır. Jeoistatistik teknikler, ölçülen noktalar arasındaki uzamsal otokorelasyonu nicelleştirir ve örnek noktalarının tahmin konumu etrafındaki uzamsal konfigürasyonunu hesaba katar. Deterministik enterpolasyon teknikleri global ve yerel olmak üzere iki gruba ayrılabilir. Global teknikler, tüm veri kümesini kullanarak tahminleri hesaplar. Yerel teknikler, daha büyük çalışma alanı içindeki daha küçük mekansal alanlar olan mahallelerdeki ölçülen noktalardan tahminleri hesaplar (Anonymous, 2021a).

ArcGIS spatial analizde bulunan enterpolasyon yöntemlerinin büyük bölümü jeoistatistikte de bulunmaktadır. Jeoistatistiksel analizde, optimum yüzeyleri elde etmek için tüm parametreler manipüle eden birçok istatistiksel model ve aracı bulunmaktadır. Ayrıca, spatial analizde bulunmayan keşifsel uzamsal veri analizi araçları da bulunmaktadır. Spatial analizde, harita cebiri, kombinasyonel operatörler ve veri dönüştürme gibi diğer alanlarda birçok işleve sahiptir. Jeoistatistik analiz ise tahmin, olasılık, nicelik ve tahmin hatasının yanında verilerin dağılımını, yersel ve küresel aykırı değerlerin belirlenmesi, küresel eğilimlerin saptanması ve verilerdeki uzamsal bağımlılığın belirlenmesi için etkileşimli bir keşifsel mekansal veri analiz araçlar seti içermektedir. Bu nedenlerden dolayı mekansal analiz, jeoistatistiksel analizin daha basit sürümüdür. Sadece basit bir enterpolasyonlu yüzeye ihtiyaç duyuluyorsa mekansal analizin kullanılması yararlı olabilir. Enterpolasyon konusunda hassasiyetin yanında detayın da önemli olduğu durumlarda kesinlikle jeoistatistik analiz yöntemi kullanılmalıdır (Anonymous, 2021b).

$\mathrm{KEH}$ 'nin ortalama yağış yüksekliğinin belirlenmesinde ArcGIS 10.4 programından yararlanılmıştır. Havza sınırları içerisine 0.0005 derecelik (diğer bir ifadeyle yaklaşık 43x43 m'lik gridler) 4153823 adet nokta verisi oluşturulmuştur.

$\mathrm{KEH}^{\prime}$ de istasyonlara göre örneklem dağılımını analiz etmek için Thiessen Poligon Metodu kullanılarak alanlar oluşturulmuş ve aşağıda verilen eşitlik yardımıyla da havzanın ortalama yağış yüksekliği hesaplanmıştır.

Port $=\Sigma$ Pi ai $/ \Sigma$ ai

Eşitlikte;

Port = Alansal ortalama yağış derinliği

ai = i. çokgenin havza içinde kalan alanı,

$\mathrm{Pi}=\mathrm{i}$. istasyonunun yağış değeri

Thiessen yönteminde birbirine yakın istasyonlar doğru parçalarıyla birleştirilir ve bu doğru parçalarından orta dikmeler çıkılarak her bir istasyona ait temsili alanlar elde edilir. Özellikle bölgedeki yağış istasyonlarının dağılımı standart 
değilse bu yöntem uygundur. Havza dışı komşu istasyonlar da kullanılabilir.

Bilindiği gibi atmosferin kalınlığı yaklaşık 10000 km'dir. Su buharı atmosferin alt bölümünde daha yoğundur. Yüksekliğe bağlı olarak yağış artışı belirli bir yüksekliğe kadar mümkün olmakta, sonrasında ise azalmaktadır. Yağışın azalmaya başladığı sınır değişkenlik göstersede Heney (1919) çalışmasında maksimum yağış kuşağının enleme bağlı olarak farklılık gösterdiğini, tropiklerde bu sınırın yaklaşık 1000 m civarında, ılıman kuşakta 1400-1500 m, kayalık dağları ve Alp Dağları'nda 3000-4000 m'yi bulduğu belirtilmektedir. Yükseklikleri belirlenen noktalar yağış değerlerini girebilmek için 13 istasyon Thiessen Poligon Metoduna göre alanlara bölünmüş ve aşağıda verilen Schreiber (1904) eşitliğinden yararlanılarak topoğrafik yükseklikleri dikkate alınarak yağış miktarları hesaplanmıştır.
$\mathrm{P} \hbar=\mathrm{P} \sigma+(54 h)$

$\mathrm{Ph}$ : Yükseltisi bilinen yağışı bulunacak bir noktanın yağışı (mm)

Po: Yağış değeri ve yükseltisi bilinen karşılaştırma istasyonun yağış tutarı ( $\mathrm{mm}$ )

$h$ : Ph ile Po arasındaki yükselti farkını (hektometre) ifade etmektedir

$\mathrm{Bu}$ formül ile birbirine eşit aralıktaki 4153823 noktanın Thiessen Poligonu Metoduna göre sınıflandırılan meteoroloji istasyonundan yağış verisini alınıp, istasyon ile arasındaki yükselti farkına göre yağış miktarı her 100 metrede 54 mm arttırılmış, örneklem noktası, meteoroloji istasyonundan daha düşük bir kotta ise azaltılarak, ArcGIS 10.4 programında hesaplanmıştır.

Yağış değerleri hesaplanan noktalar, Çizelge 3'de gösterilen hem jeoistatistik hem de mekansal analiz yöntemleri ile hesaplanmıştır.

Çizelge 3. Çalışmada Kullanılan Mekansal Analiz Yöntemleri

\begin{tabular}{ll}
\hline \multicolumn{1}{c}{ Jeoistatistik Analiz Yöntemleri } & \multicolumn{1}{c}{ Mekansal Analiz Yöntemleri } \\
\hline Inverse Distance Weighting (IDW) & Inverse Distance Weighting (IDW) \\
Radial Basis Functions (RBF) & Kriging \\
Kriging / CoKriging & Natural Neighor \\
Emprical Bayesian Kriging (EBK) & Spline \\
Kernel Smoothing & Trend \\
Diffusion Kernel & \\
\hline
\end{tabular}

\section{Bulgular ve Tartışma}

\section{Jeoistatistik Analiz Sonuçları}

Jeoistatistik analiz yönteminin temeli, değer ve mesafe arasındaki istatistiksel ilişkilere dayalıdır. Kullanılan enterpolasyon yöntemlerinde, ölçülen veriye bağlı olarak iki nokta arasındaki irtifa değeri, dünyanın eğriliği ve hata parametresi hesaba katılır. Hata kareler ortalamasının karekökü (RMSE), artıkların (tahmin hataları) standart sapmasıdır. Artıklar, veri noktalarının regresyon çizgisinden ne kadar uzakta olduğunun bir ölçüsüdür; RMSE, bu artıkların ne kadar yayıldığının bir ölçüsüdür. Diğer bir deyişle, verilerin en uygun çizgide ne kadar yoğun olduğunu gösterir. RMSE, deneysel sonuçları doğrulamak için klimatoloji, tahmin ve regresyon analizinde yaygın olarak kullanılır. Standartlaştırılmış gözlemler ve tahminler RMSE girdileri olarak kullanıldığında, korelasyon katsayısı ile doğrudan bir ilişki vardır. Örneğin, korelasyon katsayısı 1 ise, RMSE 0 olacaktır, çünkü tüm noktalar regresyon doğrusu üzerindedir ki bundan dolayı hata yoktur (Anonim, 2020).

Çizelge 4. Jeoistatistik Analiz Sonuçları

\begin{tabular}{|c|c|c|c|c|c|c|}
\hline $\begin{array}{l}\text { Geoistatiksel } \\
\text { Yöntemi / } \\
\text { Parametresi }\end{array}$ & $\begin{array}{c}\text { Inverse } \\
\text { Distance } \\
\text { Weighted }\end{array}$ & $\begin{array}{l}\text { Radial Basis } \\
\text { Functions }\end{array}$ & Kriging & $\begin{array}{c}\text { Empirical } \\
\text { Bayesian } \\
\text { Kriging }\end{array}$ & $\begin{array}{c}\text { Kernel } \\
\text { Smoothing }\end{array}$ & $\begin{array}{l}\text { Diffusion } \\
\text { Kernel }\end{array}$ \\
\hline Örnek & 4153823 & 4153823 & 4153823 & 4153823 & 4153823 & 4153823 \\
\hline Minimum & 455.22 & 453.95 & 450.94 & 450.94 & 455 & 455.89 \\
\hline Maksimum & 1619.68 & 1621.78 & 1620.97 & 1620.97 & 1620.66 & 1611.75 \\
\hline Ortalama & 738.992 & 738.99 & 738.595 & 738.96 & 748.61 & 747.95 \\
\hline Standart Sapma (SD) & 203.39 & 203.71 & 203.75 & 239.46 & 174.4 & 175.628 \\
\hline $\begin{array}{l}\text { Kareler Ortalamasının } \\
\text { Karekökü (RMS) }\end{array}$ & 3.745 & 3.21 & 3.399 & 3.289 & 3.201 & 6.808 \\
\hline $\begin{array}{l}\text { Standartlaştırılmış } \\
\text { Ortalama (MS) }\end{array}$ & & & 0.00008 & & 0.00003 & \\
\hline Standartlaştırılmış Kareler & & & & & & \\
\hline $\begin{array}{l}\text { Ortalamasının Karekökü } \\
\text { (RMSS) }\end{array}$ & & & 0.355 & & 1.164 & \\
\hline Standart Hata & & & 9.567 & 3.416 & 2.749 & \\
\hline
\end{tabular}


Çalışma kapsamında incelenen jeoistatistiksel analiz yöntemleri Çizelge 4'te sunulmuştur. Söz konusu Çizelge verileri incelendiğinde joistatistiksel yöntemlerden en iyi tahmini Kernel Smooting yöntemi vermiştir. Anılan yöntemde en düşük yağış değeri $455 \mathrm{~mm}$, en yüksek yağış değeri $1620.66 \mathrm{~mm}$, ortalama $648.61 \mathrm{~mm}$, standart sapma $174.4 \mathrm{~mm}$ ve RMS değeri $3.201 \mathrm{~mm}$ olarak hesaplanmıştır. Diğer yöntemlerle karşılaştırıldığında bu yöntem, en düşük standart sapma ve RMS değerini vermiştir. Çalışmada kullanılan diğer jeoistatistiksel yöntemlere ilişkin elde edilen sonuçlar Çizelge 4'te ve ilgili başlıklarda ayrıntılı şekilde verilmektedir.

\section{Inverse Distance Weighted}

IDW yöntemi ile hazırlanan alansal yağış dağılım haritasına (Şekil 2) göre, havzanın yüksek kesimlerinde yağış miktarı yükseklik arttıkça artış göstermektedir. Bu yöntemde hesaplanan en düşük yağış 455.22 mm, en yüksek yağış 1619.68 mm, ortalama yağış $738.99 \mathrm{~mm}$, standart sapma 203.39 $\mathrm{mm}$ ve RMS değeri $3.745 \mathrm{~mm}$ olarak hesaplanmıştır.

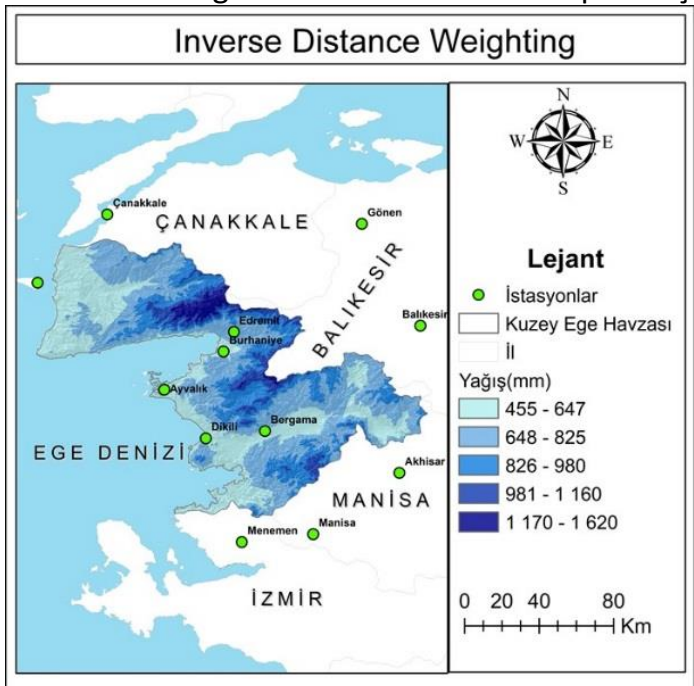

Şekil 2. IDW yönteminde havzada yağışın dağlımı

\section{Radial Basis Functions}

Radial Basis Functions yöntemi ile hazırlanan alansal yağış dağılım haritası (Şekil 3) incelendiğinde, IDW ile büyük ölçüde eşleştiği söylenebilir. Havzanın yüksek kesimlerinde yağış miktarı yükseklik arttıkça artış göstermektedir. Bu yöntemde hesaplanan en düşük yağış 453.95 mm, en yüksek yağış $1621.78 \mathrm{~mm}$, ortalama yağış 738.99 $\mathrm{mm}$, standart sapma 203.71 ve RMS değeri $3.21 \mathrm{~mm}$ olarak hesaplanmıştır.

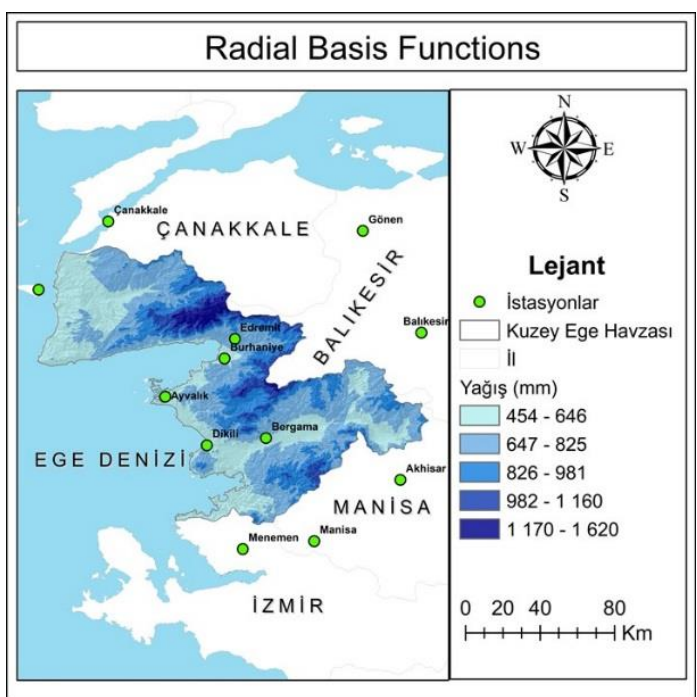

Şekil 3. Radial Basis Functions yönteminde havzada yağışın dağıımı

\section{Kriging}

Kriging (Ordinary) yöntemi ile hazırlanan alansal yağış dağılım haritası (Şekil 4) incelendiğinde, IDW ile Radial Basis Functions yöntemi ile hazırlanan haritalarla benzerlik göstermektedir. Bu yöntemde de yağışın doğası gereği yükseklik artışına bağlı olarak yağışına bağlı olarak yağış artışı net olarak görülmektedir. Bu yöntemde hesaplanan en düşük yağış 450.94 mm, en yüksek yağış: $1620.97 \mathrm{~mm}$, ortalama yağış: $738.595 \mathrm{~mm}$, standart sapma: 203.75, RMS değeri $3.399 \mathrm{~mm}$, standartlaştırılmış ortalama 0.00008 $\mathrm{mm}$, standartlaştırılmış kareler ortalamasının karekökü $0.355 \mathrm{~mm}$ ve ortalama standart hata $9.567 \mathrm{~mm}$ olarak hesaplanmıştır.

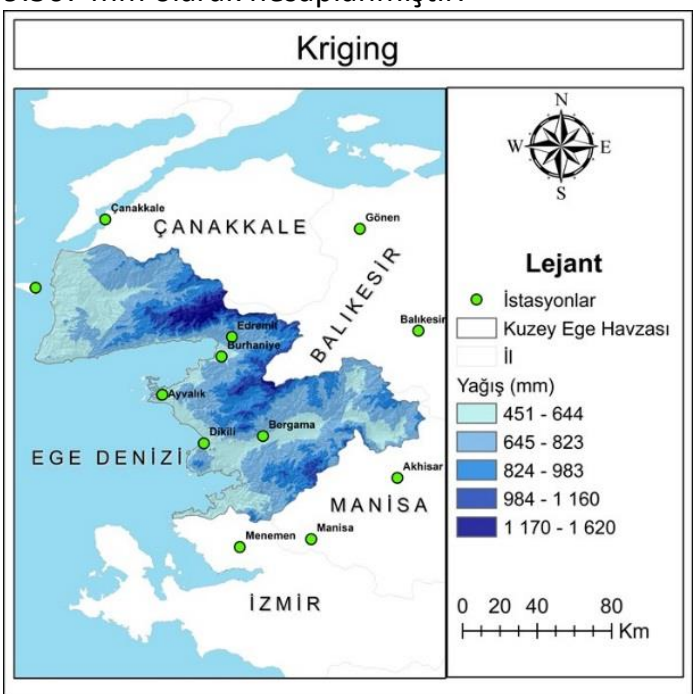

Şekil 4. Kriging yönteminde havzada yağışın dağlımı

\section{Empirical Bayesian Kriging}

Empirical Bayesian Kriging yöntemi ile hazırlanan alansal yağış dağılım haritası (Şekil 5) incelendiğinde, Kriging yöntemi ile hazırlanan 
haritayla büyük ölçüde benzerlik göstermektedir. Bu yöntemde de yağışın doğası gereği yükseklik artışına bağlı olarak yağış artışı net olarak görülmektedir. Bu yöntemde hesaplanan en düşük yağış $450.94 \mathrm{~mm}$, en yüksek yağış 1620.97 mm, ortalama yağış 738.6 $\mathrm{mm}$, standart sapma 203.75 mm, RMS değeri 3.289 $\mathrm{mm}$ ve ortalama standart hata $3.416 \mathrm{~mm}$ olarak hesaplanmıştır. Klasik krigingle karşılaştırıldığında standart sapması daha yüksek ancak RMS değeri bakımından daha düşük olarak belirlenmiştir. Bilindiği gibi Empirical Bayesian Kriging yöntemi kriging'teki modeli oluşturmada kullanılan parametreleri otomatik şekilde yapmakta (bu parametreleri bir alt küme ve simülasyon süreci aracılığıyla otomatik olarak hesaplar) ve bu nedenle de diğer kriging yöntemlerinden (doğru sonuçlar almak için parametreleri manuel olarak ayarlanmakta) daha doğru sonuçlar vermektedir.

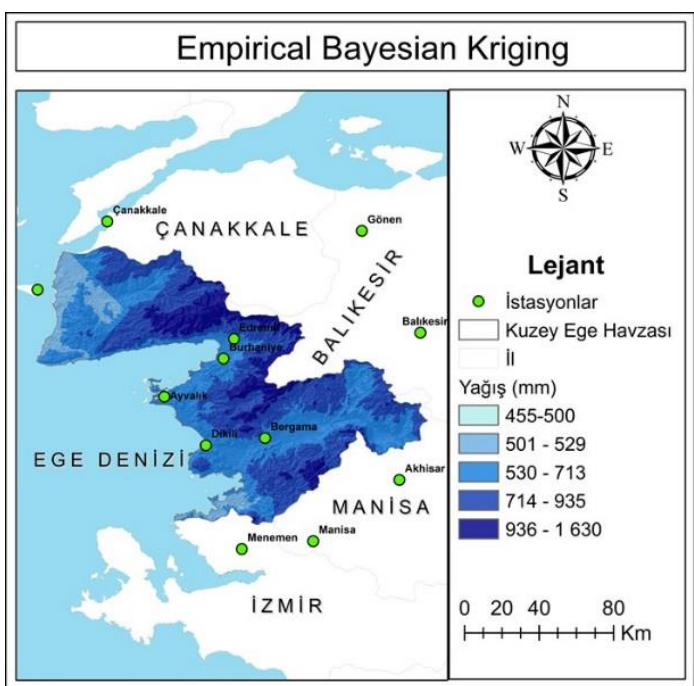

Şekil 5. Empirical Bayesian Kriging yönteminde havzada yağışın dağlımı

\section{Kernel Smoothing}

Kernel Smoothing yöntemi ile hazırlanan alansal yağış dağılım haritası (Şekil 6) incelendiğinde, Kriking ve Empirical Bayesian Kriging yöntemi ile hazırlanan haritalarla büyük ölçüde benzerlik göstermektedir. Bu yöntemde de yağışın doğası gereği yükseklik artışına bağlı olarak yağış artışı net olarak görülmektedir. Bu yöntemde hesaplanan en düşük yağış 455 mm, en yüksek yağış $1620.66 \mathrm{~mm}$, ortalama yağış $748.61 \mathrm{~mm}$, standart sapma: $174.4 \mathrm{~mm}$, RMS değeri $3.201 \mathrm{~mm}$, standartlaştırılmış ortalama: $0.00003 \mathrm{~mm}$, standartlaştırılmış kareler ortalamasının karekökü $1.164 \mathrm{~mm}$ ve ortalama standart hata $2.794 \mathrm{~mm}$ olarak hesaplanmıştır. Jeoistatistikte uygun yöntemin belirlenmesinde dikkate alınan en belirleyici parametrelerin başında gelen yöntemin RMS değeri ve standart sapma değerleri diğer yöntemlerle karşılaştırıldığında bu yöntemde en düşük olarak belirlenmiştir.

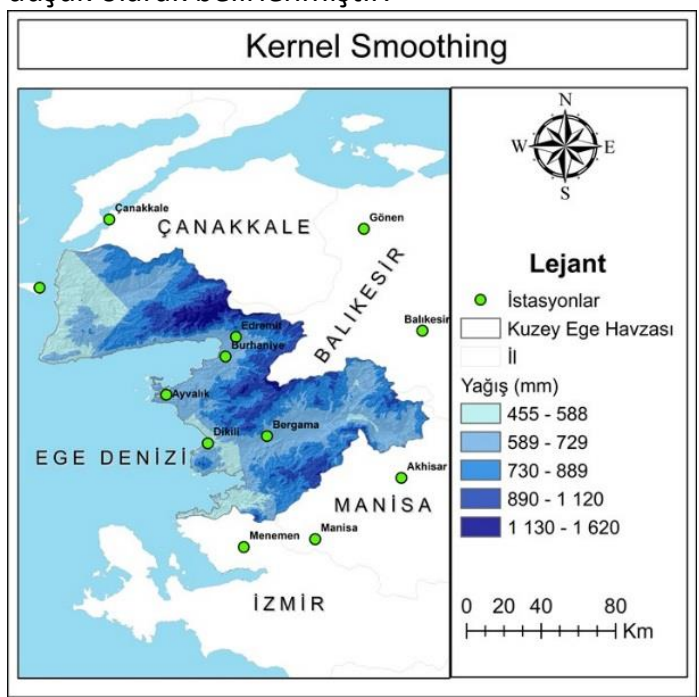

Şekil 6. Kernel Smoothing yönteminde havzada yağışın dağlımı

\section{Diffusion Kernel}

Diffusion Kernel yöntemi ile hazırlanan alansal yağış dağılım haritası (Şekil 7) incelendiğinde, IDW ve Radial Basis Functions yöntemi ile büyü ölçüde benzeştiği söylenebilir. Havzanın yüksek kesimlerinde yağış miktarı yükseklik arttıkça artış göstermektedir. Bu yöntemde hesaplanan en düşük yağış 455.89 mm, en yüksek yağış 1611.75 mm, ortalama yağış 747.95 $\mathrm{mm}$, standart sapma: $175.628 \mathrm{~mm}$ ve RMS ortalama $6.808 \mathrm{~mm}$ olarak hesaplanmıştır. Bu yöntemde elde edilen sonuçlar, Kernel Smoothing yönteminin sonuçlarıyla karşılaştırıldığında RMS değer bakımından çok yüksek, standart sapma bakımından da hafif yüksek olarak hesaplanmıştır.

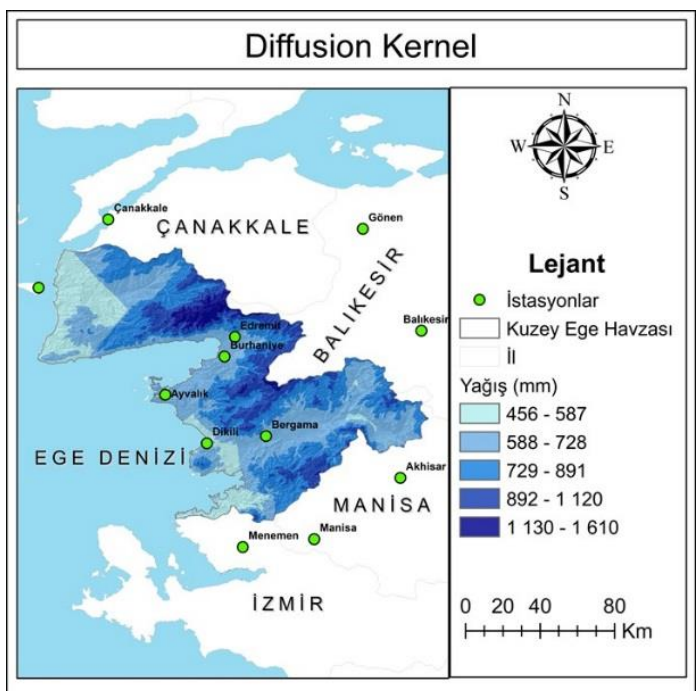

Şekil 7. Diffusion Kernel yönteminde havzada yağışın dağıımı 


\section{Mekansal Analiz Sonuçları}

Mekansal analiz, noktaların özelliklerini ve aralarındaki ilişkileri incelemede katkı sağlayan deterministik yöntemdir. Çalışma kapsamında yapılan mekansal analiz yöntemlerine ilişkin elde edilen sonuçlar Çizelge $5^{\prime}$ de gösterilmiş ve ilgili başlıklarda ayrıntılı şekilde açıklanmıştır. Anılan Çizelgeye göre standart sapması $110.99 \mathrm{~mm}$ ile Spline yöntemi KEH'nın yağış yüksekliğinin belirlenmesinde kullanılabilecek en uygun yöntem olarak belirlenmiştir. Spline yöntemine göre KEH uzun yıllar ortalama en düşük yağış 455 mm, en yüksek yağış $1612.2 \mathrm{~mm}$ ve ortalama yağış 749.81 $\mathrm{mm}$ olarak hesaplanmıştır.

Çizelge 5. Mekansal Analiz Sonuçları

\begin{tabular}{lllll}
\hline $\begin{array}{l}\text { Mekansal } \\
\text { Analiz }\end{array}$ & Min & Max & Ort. & $\begin{array}{l}\text { Standart } \\
\text { Sapma }\end{array}$ \\
\hline IDW & 455 & 1612.3 & 720.09 & 174.16 \\
Natural & 455 & 1612.3 & 748.03 & 187.51 \\
Neighbor & & & & \\
Kriking & 455 & 1618.5 & 738.96 & 203.93 \\
Spline & 455 & 1612.2 & 749.81 & 110.99 \\
\hline
\end{tabular}

\section{Inverse Distance Weighted}

IDW yöntemi ile hazırlanan alansal yağış dağılım haritasına (Şekil 8) göre, havzanın yüksek kesimlerinde yükseklik arttıkça yağış miktarı da artış göstermektedir. Bu yöntemde hesaplanan en düşük yağış: $455 \mathrm{~mm}$, en yüksek yağış: $1612.3 \mathrm{~mm}$, ortalama yağış: $720.09 \mathrm{~mm}$ ve Standart Sapma: $174.16 \mathrm{~mm}$ olarak hesaplanmıştır.

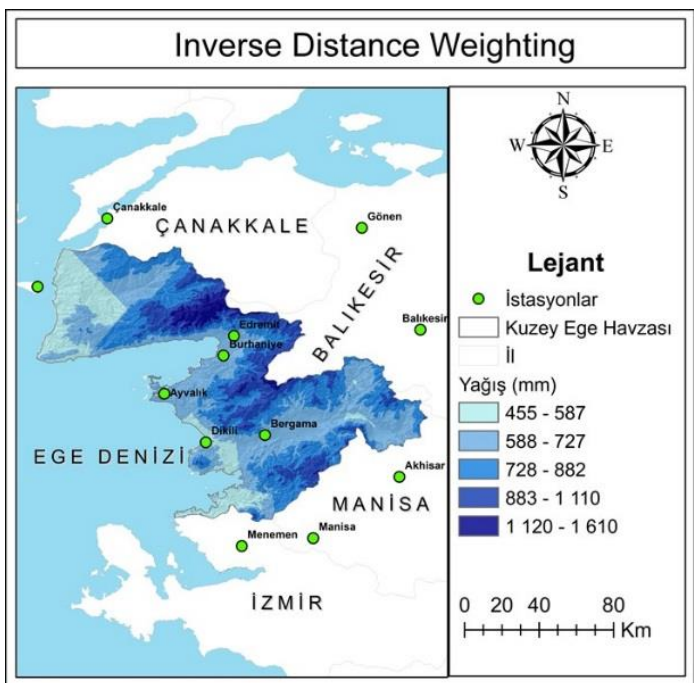

Şekil 8. Inverse Distance Weighted yönteminde havzada yağışın dağlımı

\section{Kriging}

Kriging yöntemi ile hazırlanan alansal yağış dağılım haritasına (Şekil 9) göre, havzanın yüksek kesimlerinde yağış miktarı yüksekliğin artışına paralel olarak artış göstermektedir. Bu yöntemde hesaplanan en düşük yağış: $455 \mathrm{~mm}$, en yüksek yağış: $1618.5 \mathrm{~mm}$, ortalama yağış: $738.96 \mathrm{~mm}$ ve Standart Sapma: 203.93 mm olarak hesaplanmıştır.

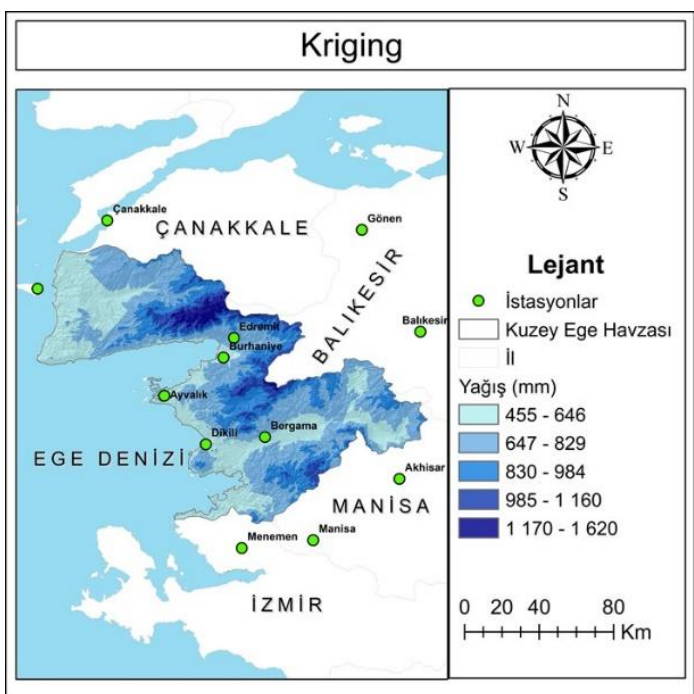

Şekil 9. Kriging yönteminde havzada yağışın dağlımı

\section{Natural Neighbor}

Natural Neighbor yöntemi ile hazırlanan alansal yağış dağılım haritasına (Şekil 10) göre, havzanın yüksek kesimlerinde yağış miktarı yüksekliğin artışına paralel olarak artış göstermektedir. Bu yöntemde hesaplanan en düşük yağış: $455 \mathrm{~mm}$, en yüksek yağış: $1612.3 \mathrm{~mm}$, ortalama yağış: $748.03 \mathrm{~mm}$ ve Standart Sapma: $187.51 \mathrm{~mm}$ olarak hesaplanmıştır.

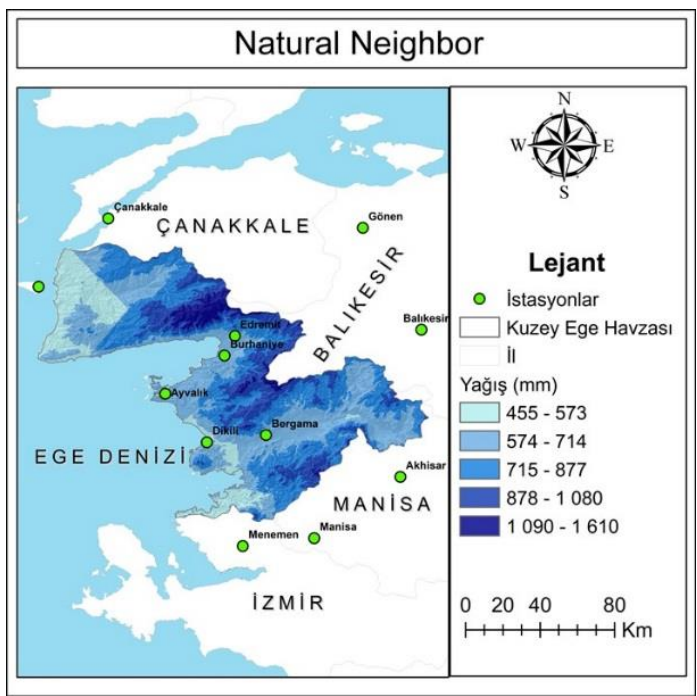

Şekil 10. Natural Neighbor yönteminde havzada yağışın dağlımı

Spline

Spline yöntemi ile hazırlanan alansal yağış dağılım haritasına (Şekil 11) göre, havzanın yüksek kesimlerinde yağış miktarı yüksekliğin artışına 
paralel olarak artış göstermektedir. Bu yöntemde hesaplanan en düşük yağış: $455 \mathrm{~mm}$, en yüksek yağış: $1612.2 \mathrm{~mm}$, ortalama yağış: $749.81 \mathrm{~mm}$ ve Standart Sapma: 110.99 mm olarak hesaplanmıştır.

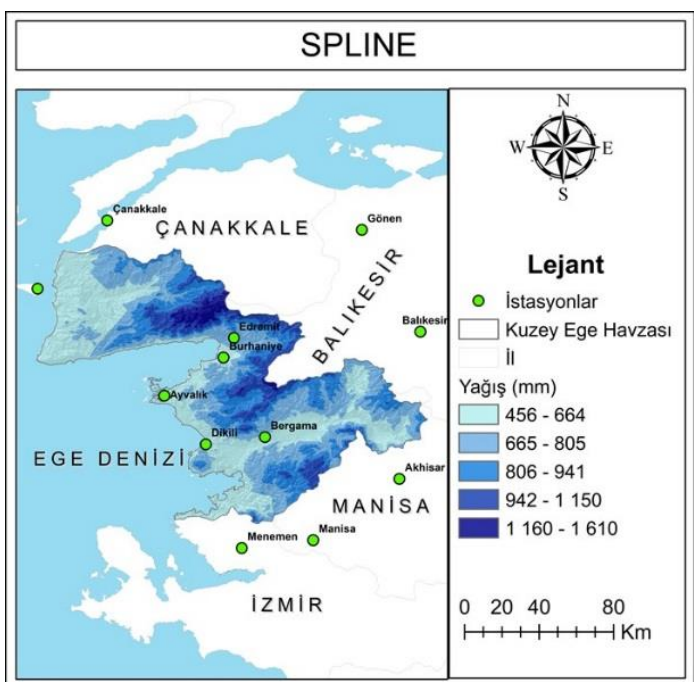

Şekil 11. Spline yönteminde havzada yağışın dağlımı

Aydın ve Raja (2016) yağış modeli konusunda yaptıkları çalışmalarında, jeoistatisitk yöntemle oluşturulan yağış modelinin deterministik yöntemlerle oluşturulanlardan daha doğru sonuçlar verdiğini rapor etmektedirler.

Hidrometeorolojik ölçümler doğası gereği olasılığa bağlı değişkenlerdir. Alansal tahminlerde, esas bileşenler analiz yönteminin kullanılması uygundur. Söz konusu yöntemle kısa periyotlu istasyonlardaki kaydedilmemiş verileri ve hiç gözlem yapılmamış noktalardaki değerler tahmin edilebilmektedir (Önsoy ve Bayram, 2011a). Türkiye'nin 40 istasyona ait yağış verileri (1929-1972 periyodunda gözlemlenen) esas bileşenler analizine tabi tutulduğunda, büyük alanlarda hatanın da büyüdüğü, bu nedenle küçük havzalarda uygulamanın gerçeğe daha yakın sonuçlar verebileceği düşünülmektedir (Önsoy ve ark., 2011; Çıtakoğlu ve ark., 2017).

Çıtakoğlu ve ark., (2017) Türkiye sınırları içerisinde yer alan 20 yıl ve daha fazla kayıt uzunluğuna sahip 200 adet yağış gözlem istasyonunun Ocak-Aralık dönemine ait aylık ortalama yağış değerlerini kullanarak dört mevsim yağış haritalarını jeoistatistiksel yöntemle hazırlamışlardır. Mevsimsel yağışların mekânsal değişimi Kiriging enterpolasyon yöntem ve Gaussian tip yarıvariogram kullanılarak jeoistatistik yöntem kullanılarak yeterli doğrulukta tahmin edilebileceği rapor edilmiştir. Javari (2017) tahmin hatalarına dayalı jeoistatistik teknikleri karşılaştırarak, 170 istasyon ve 39042 yağış noktasından İran için günlük yağışların ortalama değerlerinin bazı mekansal değişkenlik simülasyonlarını yapmış ve çalışma sonucunda Kernel Smoothing enterpolasyon yöntemini yağış yüksekliğinin belirlenmesinde kullanılabileceğini dile getirmektedir. Krivoruchko ve Gribov (2019)'un yaptıkları çalışmada, Güney Afrika'daki ortalama yıllık yağış ve gündüz kara yüzey sıcaklığı uydu verileri karşılaştırılmış ve Empirical Bayesian Kriging, Rastgele Fonksiyon Kriging (Intrinsic Random Function Kriging-IRFK) ve Doğrusal Karışık Model Kriging (Simple Kriging LMM olarakta ifade edilen) Kriging yöntemleri ile karşılaştırılmış ve sonuçta veri karmaşıkığını gidererek daha fazla performans gösterdiği belirlenmiştir. Çiçek ve Ataol (2009) yaptıkları çalışmada, yüksekliğinde dikkate alınarak yapılan $\mathrm{KEH}$ 'nin ortalama yağış yüksekliği hesaplamasında alansal havza ortalama yağış yüksekliği 776.7 mm olarak belirlenmiştir. Anılan araştırıcılar yükseklik gruplarının temsil edebilmek için CBS ortamında 0.2 derecelik eşit aralıklarla (yaklaşık $20 \mathrm{~km}$ aralıklarla) noktalar oluşturulmuşlar ancak yapılan bu çalışmada 0.0005 derece (43 $\mathrm{m}$ aralıklarla) eşit aralıklarla noktalar oluşturulmuş olup çok daha hassas bir veri seti oluşturulmuştur. Soulis ve ark., (2018) Yunanistan'da 140 meteoroloji istasyonunun dikkate alarak yaptıkları çalışmada, alansal yağış hesaplamasında jeoistatisitik yöntemlerinden cokrigin-simple cokriging yönteminin ve semivariogram tipi olarakta exponential'in alansal yağış hesaplamasında en iyi sonucunu verdiğini dile getirmektedirler. Ayrıca çalışmada, Ortalama Hata (ME) 52-64 mm, RMSE değeri, 158-184 ve RMSSE 0.82-1.07 arasında değişim gösterdiğini rapor etmişlerdir. Silva ve ark., (2019) Brezilya'nın Pernambuco eyaleti için aylık yağışların mekansal dağılımını tahmininde kullanılabilecek en uygun jeoistatistiksel yöntemi belirlemek amacıyla yaptıkları çalışmada, 26 farklı enterpolasyon şemasını içeren 7 farklı jeoistatistik yaklaşımı (IDW, Shepard modified, Natural neighbor, Nearest neighbor, Radial basis function, Kriging, Trend surface analysis) incelemişlerdir. Çalışma sonunda trend surface analysis yöntemi en iyi sonucu verirken onu natural neighbor, IDW ve kriging yöntemleri izlemiştir. Trend surface analysis yönteminde MAE değeri 26.37, MSE değeri 1911.15, RMSE değeri 43.72 ve ME değeri 0.76 olarak hesaplanmıştır. Zhang ve ark., (2018) Tropikal Yağış Ölçüm Misyonu için Beş enterpolasyon yönteminin (IDW, Spline Regularized, Spline Tension, Ordinary Kriging, Simple Kriging) göstergeleri (RMSE ve MAE) dikkate alınarak yapılan seçimde Simple kriging yöntemi 95.56 RMSE değeri ve 66.86 MAE değeri ile en uygun yöntem olarak belirlenmiştir.

Sadeghi ve ark., (2017) 30 yıllık rasatı olan 35 sinoptik istasyondan alınan yağış ortalama verilerinde jeoistatistik yöntemler (kriging, cokriging, inverse distance weighting (IDW), radial 
basis function, global polynomial interpolation, ve local polynomial interpolation) ile karşılaştırılmıştır.En iyi sonuç, co-kriging (ortalama mutlak bağıl hata (MARE) 0.124 ve $0.75 R^{2}$ değeri) yönteminde elde edilmiştir. Cezayir'in kuzeybatı bölümünde yer alan Chéliff havzası, mekansal olarak çok çeşitli yağış rejimlerine sahip bölgelerdendir. Söz konusu bölgenin ortalama yağış yüksekliğinin belirlemek amacıyla 58 meteoroloji istasyonu dikkate alınarak bir çalışma gerçekleştirilmiştir. Jeoistatisitik yöntemlerinden Ordinari kriging (OK), regression-kriging (RK), ve external drift kriging (KED) yöntemleri kullanılarak ortalama yağış yüksekliği haritaları hazırlanmıştır. Çalışma sonucunda, KED yöntemi (RMSE= -1.9; korelasyon katsayısı $=0.82$ ) en iyi sonucu verirken onu RK (RMSE= 35.4; korelasyon katsayısı $=0.79$ ) ve OK (RMSE= 49.5; korelasyon katsayısı $=0.70)$ takip etmiştir. Yükseklik hesaba katıldığında tahmin performansıaçısından KED yöntemi en iyi sonuç veren yöntemdir (Rata ve ark., 2020). Kayhan ve Alan (2012), KEH için her bir pikselin 1 hektar alanı temsil ettiği durumda havza için 996317 adet piksel oluşturmuşlar ve havza alanını 9963.17 km² olarak hesaplamışlardır. 1971-2010 yağış ölçüm periyodu verileri dikkate alınarak yapılan hesaplama sonucunda havzanın alansal yağış yüksekliği 616 $\mathrm{mm}$ olarak hesaplanmıştır. Yapılan çalışmadan elde edilen sonuçtan oldukça farklıdır. Bunun nedeni olarak söz konusu araştırıcıların yükseklik-yağış ilişkisini hesaplamalarında dikkate almamaları ve piksel alan değerinin farklılığından kaynaklandığı düşünülmektedir. Zira yapılan bu çalışmada, her bir pikselin alanı yaklaşık 0.185 hektardır.

\section{Sonuç ve Öneriler}

Mümkün olduğunca basit bir şekilde, spatial analiz enterpolasyon yönteminde, yalnızca değer ve mesafeye dayalı olarak matematik enterpolasyon gerçekleştirilir (bu nedenle, iki nokta arasındaki irtifa değerini hesaplamak için basit bir doğrusal enterpolasyon yöntemi uygulanabilir). Jeoistatistik analiz yönteminde ise değer ve mesafe arasındaki istatistiksel ilişkilere dayalı enterpolasyon gerçekleştirilir (bu nedenle iki nokta arasındaki irtifa değerini hesaplamak için dünya eğriliği ve hatta gerçek veri hesaba katılır). Birincisi topografya için uygunken, ikincisi diğer yüzeyler için özellikle veri noktaları arasındaki mesafenin büyük ve düzensiz olduğu durumlarda uygundur. KEH drenaj havzasının içerisinde 5 ve çevresinden de 8 meteoroloji istasyonunun uzun yıllar ortalama yağış değerleri dikkate alınarak hem jeoistatisitiksel (6 adet) hem de farklı spatial analiz (4 adet) yöntemleri kullanılarak Kuzey Ege Drenaj Havzasının ortalama yağış yüksekliği belirlenmiştir. İstasyon değerlerinin alana yayılmasında seçilecek grid boyutları sonuçları büyük oranda etkilemektedir. Çalışma kapsamında 43×43 m gridler oluşturulmuş ve bu gridlerin merkezi nokta verisi olarak (4153823 adet) dikkate alınmıştır. Söz konusu noktaların verisi de Schreiber (1904) eşitliğinden yararlanılarak (yükseklik düzeltmesi yapılarak) hesaplanmıştır. Mekânsal analizlerde veri setinin alanı temsil yeteneğinin yeterli olması sonuçların güvenilirliğini artırır.

Ortalama yağış yüksekliğinin hesaplandığı koşullarda drenaj havzası dışındaki istasyonların mümkün olduğunca dikkate alınmaması yerinde bir uygulama olabilir. Yağış değerleri sıcaklık değerleri gibi bir dağılım göstermemektedir. Bu nedenle drenaj havzasını alansal yağış yüksekliği belirlenirken hataların artmasına neden olur. Havza dışı istasyonlar hesaplamaya dahil edildiğinde ortalama yağış yüksekliği, olandan daha düşük ya da yüksek olarak hesaplanabilir. Özellikle KEH gibi drenaj havzalarının çevresindeki yağış istasyonlarının dikkate alınması durumunda, hesaplanan ortalama yağış yüksekliği, çevre istasyonlardaki yağış düşüklüğünden dolayı daha düşük olarak hesaplanmıştır. KEH topoğrafik yapısı itibarıla çevre drenaj havzalarında oldukça farklıdır. Bu da söz konusu havzanın yağış yüksekliğinin doğru tahmin edilmesinde hataya neden olmaktadır. Havza dışı istasonların dikkate alındığı durumda Kuzey Ege Drenaj Havzasının alansal ortalama yağış yüksekliğinin hesaplanmasında jeoistatistiksel yöntemlerden Kernel Smoothing yönteminin, spatial analiz yöntemlerinden ise Spline yönteminin kullanılabileceği söylenebilir.

\section{Kaynaklar}

Anonim, 2012. Havza Koruma Eylem Planlarının Hazırlanması-Kuzey Ege Havzası. TÜBiTAK MAM Çevre Enstitüsü. Erişim linki: www.tarimorman.gov.tr/SYGM/ Belgeler/havza\%20koruma\%20eylem\%20pla nlar\%C4\%B1/Kuzey_Ege_Havzasi.pdf.

Anonim, 2017. Kuzey Ege Havzası Koruma Eylem Planı. Orman ve Su işleri Bakanlığı Su yönetimi Genel Müdürlüğü. Ankara, Türkiye.

Anonim, 2019. Kuzey Ege Nehir Havzası Yönetim Planının Hazırlanması Projesi Kapsamlaştırma Raporu. Ankara: Çınar Mühendislik Müşavirlik A.Ş.

Anonim, 2020. Web Sayfası. Erişim adresi: https://www.statisticshowto.com/probabilit $\mathrm{y}$-and-statistics/regression-analysis/rmseroot-mean-square-error/. Erişim Tarihi: 25.12.2020

Anonymous, 2004. Using Arcview GIS. Environmental System Research Institute. ESRI. Redlans, California. 
Anonymous,

2021a.

https://gis.stackexchange.com/questions/4

5316/difference-between-geostatistical-

analyst-and-spatial-analyst-toolboxes-forinte Erişim Tarihi: 14.01.2021

Anonymous, 2021b. Web sayfası. Adresi: https://pro.arcgis.com/en/proapp/latest/help/analysis/geostatisticalanalyst/deterministic-methods-for-spatialinterpolation.htm. Erişim Tarihi:12.12.2020.

Anteplioğlu O. Şen O., 1994: İstanbul Kandilli Rasathw1esi Yağış Verilerinin istatistiksel Analizi. 1. Ulusal Hidroıneteoroloji Semp. 2325 Mart 1994, İstanbul, 210-219.

Aydın O., Raja N.B., 2016. Yağışın Mekânsal Dağılışında Deterministik ve Stokastik Yöntemler: Mauritius örneği, Doğu Afrika. Coğrafi Bilimler Dergisi (CBD) 14 (1), 1-14

Buttafuoco G., Lucà F., 2020. Accounting for Elevation and Distance to The Nearest Coastline in Geostatistical Mapping of Average Annual Precipitation. Environmental Earth Sciences (2020) 79:11.

Büke E., 2019. Kuzey Ege Havzası Makrofit Kompozisyonunun Belirlenmesi. Kuzey Ege Havzası Makrofit Kompozisyonunun Belirlenmesi. Tekirdağ, Türkiye: T.C. Tekirdağ Namık Kemal Üniversitesi Fen Bilimleri Enstitüsü.

Chaubeya I., Haana C.T., Grunwaldb S., Salisburyc J.M., 1999. Uncertainty in The Model Parameters Due To Spatial Variability Of Rainfall. Journal of Hydrology Vol 220, 48-61.

Çetin M. 1996. Jeoistatistiksel Yöntem ile Nokta ve Alansal Yağışların Saptanması ve Stokastik Olarak Modellenmesi Örnek Havza Uygulamaları. Çukurova Üniversitesi Fen Bilimleri Enstitüsü, Tarımsal Yapılar ve Sulama Anabilim Dalı, Doktora Tezi, Adana.

Çıtakoğlu H., Çetin M., Çobaner M., Haktanır T., 2017. Mevsimsel Yağışların Jeoistatistiksel Yöntemle Modellenmesi ve Gözlemi Olmayan Noktalarda Tahmin Edilmesi. iMO Teknik Dergi, 2017, 28 (1), 7725 - 7745.

Çiçek i., Ataol M., 2009. Türkiye'nin Su Potansiyelinin Belirlenmesinde Yeni Bir Yaklaşım|. Coğrafi Bilimler Dergisi, Cilt:7(1), 51-56.

Daly C., Neilson R.P., Phillips D., 1994. A Statisticaltopographical Model for Mapping Climatological Precipitation Over Mountainous Terrain. Journal of Applied Meteorology, 33(2): 140-158.

Diaz H.F., Karl T.R., 1994. Information Needs For Precipitation-Sensitive Systems NOAA Environmental Watch Reprt 94:1, U.S. Dept. of Commrece, National Ocean and Atmospheric Administration.

Faures J.M., Goodrich D.C., Woolhiser D.A, Sorooshian S., 1995. Impact of Small- Scale Spatial Variability On Runoff Modeling. Journal of Hydrol., 173, 309-326.

Güler M., Kara T., 2007. Alansal Dağılım Özelliği Gösteren İklim Parametrelerinin Coğrafi Bilgi Sistemleri İle Belirlenmesi ve Kullanım Alanları; Genel Bir Bakış. OMÜ Zir. Fak. Dergisi, 2007,22(3): 322-328.

Heney A. J., 1919. Increase of precipitation with altitude. Monthly Weather Review 47:1, 3341.

Isaaks E.H., Srivastava R.M., 1989. Applied Geostatistics. Oxford University Press, Inc., USA.

Javari M., 2017. Geostatistical modeling to simulate daily rainfall variability in Iran. Cogent Geoscience (2017), 3: 1416877.

Kayhan M., Alan i.,, 2012. Türkiye Alansal Yağış Analizi 1971-2010. MGM Yayınları. https://www.mgm.gov.tr/FILES/genel/kitapl ar/alansalyagisanalizi.pdf

Keskiner A.D., 2008. Farklı Olasılıklı Yağış ve Sıcaklıkların CBS Ortamında Haritalanmasında Uygun Yöntem Belirlenmesi ve M. Turc Yüzey Akış Haritasının Geliştirilmesi: Seyhan Havzası Örneği. Çukurova Üniversitesi, Fen Bilimleri Enstitüsü, Yüksek Lisans Tezi, Adana.

Krivoruchko K., Gribov A., 2019. Evaluation of Empirical Bayesian Kriging. Spatial Statistics 32 (2019) 100368.

Lekesiz H.Ö., 2018. Kuzey Ege Havzası Akarsuları Diyatome Kompozisyonu ve Ekolojik Özellikleri. Gaziantep Üniversitesi Fen Bilimleri Enstitüsü. Yüksek Lisans Tezi, Gaziantep.

Ölgen M.K., 2010. Türkiye'de Yıllık ve Mevsimsel Yağış Değişkenliğinin Alansal Dağılımı. Ege Coğrafya Dergisi, 19/1 (2010), 85-95, İzmir.

Önsoy H., Bayram A., 2011b. Yağış Verileri ve MTH Yöntemiyle Su Potansiyelinin Hesabı. 5. Ulusal Su Mühendisliği Sempozyumu, 12-16 Eylül 2011 İstanbul, 361-373.

Önsoy H., Bayram A., 2011a. MTH Yöntemi Hidrolojik Değişkenlerin Enterpolasyonu. 5. Ulusal Su Mühendisliği Sempozyumu, 12-16 Eylül 2011 İstanbul, 337-345.

Önsoy H., Kömürcü M.İ., Bayram A., 2011. Esas Bileşenler Yöntemi ve İklim Bölgelerinin Analizi, 5. Ulusal Su Mühendisliği Sempozyumu, 12-16 Eylül 2011 İstanbul, 315-326.

Rata M., Douaoui A., Larid M., Douaik A., 2020. Comparison of Geostatistical Interpolation 
Methods to Map Annual Rainfall in The Chéliff Watershed, Algeria. Theoretical and Applied Climatology 141:1009-1024.

Sadeghi S.H., Nouri H., Faramarzi M., 2017. Assessing the Spatial Distribution of Rainfall and the Effect of Altitude in Iran (Hamadan Province). Air, Soil and Water Research 10: 17.

Schreiber P., 1904: Uber die Beziehungen zwischen dem Niederschlag und der Wasserfu hrung der Flusse in Mitteleuropa. Meteor. Z., 21, 441-452.

Silva A.S.A., Stosic B., Menezes R.S.C., Singh V.P., 2019. Comparison of Interpolation Methods for Spatial Distribution of Monthly Precipitation in the State of Pernambuco, Brazil. J. Hydrol. Eng., 2019, 24(3).

Soulis 1 K.X., Kalivas D.P., Apostolopoulos C., 2018. Delimitation of Agricultural Areas with Natural Constraints in Greece: Assessment of the Dryness Climatic Criterion Using Geostatistics. Agronomy 2018, 8, 161.

Şen Z., 1994: Yüzde Ağırlıklı Polinom Yöntemi ile Alansal Yağış Hesabı. 1. Ulusal Hidrometeoroloji Sempozyumu, 23-25 Mart 1994, İstanbul, 124-132.

Toros H., Karan H., Deniz A., 1994: Batı Anadolu Yağışlarının Gruplama (Cluster) Analizi. 1. Ulusal Hidrometeoroloji Semp. 23-25 Mart 1994, İstanbul, 220-230.

Tural S., 2011. Gerçek Zamanlı Meteoroloji Verilerinin Toplanması, Analizi ve Haritalanması. Ankara Üniversitesi Fen Bilimleri Enstitüsü, Yüksek Lisans Tezi, Ankara.

Zhang Y., Li Y., Ji X., Luo X., Li X., 2018. FineResolution Precipitation Mapping in a Mountainous Watershed: Geostatistical Downscaling of TRMM Products Based on Environmental Variables. Remote Sens. 2018, 10, 119; doi:10.3390/rs10010119. 